\title{
COMPARATIVE STUDY OF CLASSICAL GREEK ETHICS AND ISLAMIC ETHICS
}

\author{
Endrika Widdia Putri \\ UIN Sunan Kalijaga Yogyakarta \\ E-mail: endrikawiddiaputri@yahoo.co.id
}

\begin{abstract}
The notion that Islamic ethics originate from Classical Greek ethics needs examination. It is true that Muslim thinkers or scholars who wrote works on ethics were influenced by classical Greek philosophers. However, there are strong fundamental characters that distinguish Islamic ethics from Greek ethics. This study aims to highlight these differences and critically shows that such differences come from philosophical and ethical principles. Base on a comparative study of Muslims and Greek philosophers, this study shows that in substance, the style of Islamic ethics is very different from Classical Greek ethics. While Classical Greek ethics reveals its fundamental character of atheism, focusing on human relationship while releasing faith in its discussion, Islamic ethics tends to expose the characters of theism. Its discourse reaches the level of spirituality that covers not only inter-human relationships but also the relationship between humans and God. It also refers to the scriptural sources such as the Qur'an and Hadith and Islamic ethics related to faith. Nevertheless, both of them have commonalities in the relationship between ethics and happiness, which become the highest goal of ethics in both traditions.
\end{abstract}

Keywords: Classical Greek Ethics, Islamic Ethics, Ethics in the Millennium era

DOI: https://doi.org/10.20414/ujis.v23i1.346

\section{Introduction}

ETHICAL ISSUES issues are always relevant to discuss because ethics are related to humans and creatures and such connections are unique and complicated. It is essential for humans, who are the subject of ethics, to know how good ethics is a guide to life. Ethics does not make all humans pleasant because there are many other aspects that determine behaviours, but it can open their eyes to see 
good and evil. The existence of ethics will give a guide on how to behave with God, humans and nature or the environment.

Discussions on ethics have begun since as early as the time of classical Greeks, although such discussion touched on a straightforward definition or conception of ethics and not yet a comprehensive concept of ethics. However, philosophical ideas about classical Greek ethics were at least beneficial for young Greek Athens at the time. Socrates (469 - 399 BC) was predicted as a builder (pioneer) of morality because he was the first philosopher who tried earnestly to formulate human relations with the basis of science. ${ }^{1}$ After that came two groups who were followers of Socrates, namely Cynics (444 - 370 BC) and Crenics. According to Cynics, divinity is clean of all needs, and the best of humans are those who are in accordance with the divine character. $^{2}$ If it is associated with happiness, then for Cynic, happiness is to avoid all deliciousness. As for Crenics, the opposite is exact, for him to seek delicacy and stay away from pain is the only real purpose for life, and the action is named after the greater delicacy of pain. ${ }^{3}$ Thus, happiness for him is achieving delicacy.

Then came Plato (427 - 347 BC) a student from Socrates, he agreed with his teacher Socrates that knowledge is a virtue, between knowledge and virtue having interrelated relationships. However, in explaining his ethics, Plato emphasized the concept of ideas and virtues that function as controlling the soul. ${ }^{4}$ After that, Aristotle, who was a student from Plato, emerged, arguing that humanity's fundamental goal is happiness. He concluded that happiness is the activity of the soul to conform to perfect virtue. ${ }^{5}$

After that, came Stoics and Epicurics. About ethics, Stoics agrees with Cynics. Stoics' understanding was followed by many philosophers in Greece and Rome, and his famous followers at the beginning of the Roman empire, namely Seneca, Epictetus, and

${ }^{1}$ Ahmad Amin, Etika (Ilmu Akhlak) (Jakarta: Bulan Bintang, 1983), 142.

2 Ibid., 142-143.

3 Ibid., 143.

${ }^{4}$ Samuel Enoch Stumph and James Fieser, Socrates to Sartre and Beyond: A History of Philosophy, 8th ed. (New York: McGraw-Hill, 2008), 53.

5 Ali Maksum, Pengantar Filsafat: Dari Masa Klasik hingga Postmodernisme (Yogyakarta: Ar-Ruzz Media, 2011), 91. 
Emperor Marcus Orleus. For Stoics, delicacy is not a goal for humans, and it is not always right, but that goal is to achieve virtue because it is the main. ${ }^{6}$ Epicurics agrees with Cyrenics. ${ }^{7}$ For him, pleasure is a good virtue and human nature. ${ }^{8}$ The more obvious for Epicurics or Epicurean pleasure is the absence of pain in the body and chaos in the soul..$^{9}$ Thus, Epicureanists avoid what is called pleasure which will lead one to inner pain and suffering.

Subsequent developments, at the end of the third century AD, spread Christianity in Europe. Religion can change the human mind and bring moral principles in the law. Likewise also gives a lesson to humans that the Lord is the source of all morals. Christianity expects humans to try to purify themselves, both their thoughts and actions indeed. Religion makes the soul full power regarding the body and desire (lust). Therefore, most of the first followers of this religion, like to ignore their bodies, get rid of the mortal world, and like zuhud. ${ }^{10}$

In its development, as is known, ethics is not only discussed by the Greeks but also developed into the Islamic world. Ethics in the view of Muslim philosophers is very different from what is believed by Greek philosophers. Although, in discussing ethics, both Greek philosophers and Muslim philosophers believe in a correlation between ethics and happiness. Looking at the development of ethics in the Islamic world, one may assume that Islamic ethics have little or even no difference from Greek ethics. Such an opinion or opinion becomes a crucial underlying reason to study more in-depth between Classical Greek ethics and Islamic ethics. Is Islamic ethics a copy-paste of Classical Greek ethics or not.

Furthermore, looking at the condition of the millennial generation as described previously, the current millennial generation needs ethics as a guidebook for good morals in using existing technologies, especially gadgets. Neither Classical Greek

${ }^{6}$ Amin, Etika, 110.

7 Ibid., 145.

8 Peter Singer, Ethics (England: Oxford Readers, 1994), 189.

9 A. Mangunhardjana, Isme-Isme dalam Etika dari A sampai Z (Yogyakarta: Penerbit Kanisius, 1997), 83.

${ }^{10}$ Amin, Etika, 145-146. 
ethics nor Islamic ethics want anyone to destroy humanity. Both of them direct human beings to live in a good life in the world and the hereafter. Classical Greek philosophers, such as Socrates, Plato, Aristotle, to mention some, of course, want harmonization between humans and their behaviour to create perfect morality. Through ethics, it is hoped that humans will be good at treating, using and making the best use of all existing technological developments, especially gadgets, so that they will bring happiness to human life.

Furthermore, referring to the thoughts of Muslim philosophers in the field of ethics not only explain what is right and proper actions but also at the same time, order to follow the teachings about good deeds. ${ }^{11}$ This means that the purpose of the study of ethics is to apply good ethics to everyday life so that humans can achieve the noble goals of happiness. As long as humans still live in this world, they will never be separated from ethics because humans are the subject of ethics so that all of their behaviours is an ethical study. Related to utilizing technology, especially gadgets, humans should understand philosophical ethics in using gadgets. The core ethical philosophy of Muslim philosophers teaches humans that the last estuary of all its activities is happiness. Therefore, if you look at the use of gadgets at this time, people should be able to use gadgets that they have as positive as possible for things that have useful values and benefits.

Humans need ethics that will lead them to ultimate happiness. Ethics is very necessary to address problems that occur in the era of the current millennial generation. However, human life in this millennial era must continue to be carried out; all obstacles must be faced because life is a journey of love. As Haidar Baqir said "human life is a journey of love, although not many realize it. Starting from the fall and connected with the desire to go home. Human life is a journey to go and go home, from a place of departure $\left(m a b d a^{\prime}\right)$ to a place back (ma'ad), which is none other

${ }^{11}$ Mustain, "Etika dan Ajaran Moral Filsafat Islam: Pemikiran Para Filosof Muslim tentang Kebahagiaan," Ulumuna 17, no. 1 (2013): 191, accessed November 11, 2018, https://ulumuna.or.id/index.php/ujis/article/view/239. 
than the place of departure as well, humans originated and originated from God to walk back to God. ${ }^{12}$

Based on the explanation above, it is crucial to study Islamic ethics and compare it with Classical Greek ethics and Islamic ethics. This study wants to challenges the assumption that both ethics are similar. Islamic ethics is indeed influenced by Classical Greek ethics ${ }^{13}$ However, it has its own concept, which is very different from its predecessor. Therefore, this paper, in particular, will examine the similarities and differences between classical Greek ethics and Islamic ethics. In doing so, it will present some figure of the ethic philosopher from both traditions and analyze their encounter and how this results in both similarities and differences.

\section{Classical Greek Ethics}

One of the uniqueness of Classical Greek Ethics is the emphasis between good relations and happiness. ${ }^{14}$ This could be due to the peak of the Greek philosopher's thinking, which was able to map that goodness could lead to happiness, such as ethical thought Socrates, Plato, and Aristotle. For Socrates, ethics has a good relationship with virtue, so the essence of the ethical thinking of Socrates is a person who is knowledgeable by himself goodhearted. Therefore, for Socrates, the mind or ethics is to know. Who knows the law must act according to his knowledge. There cannot be a conflict between beliefs and deeds. Because the mind is based on knowledge, then the mind can be learned. ${ }^{15}$ So, the more human knowledge about ethics, the better the ethics. Knowledge is very instrumental in shaping human ethics.

${ }^{12}$ Haidar Baqir, Islam Risalah Cinta dan Kebahagiaan (Jakarta: Mizan, 2012), 34.

13. On an example of contemporary work is by Mahmood. See Saba Mahmood, The Politics of Piety: The Islamic Revival and the Feminist Subject (Princeton: Princeton University Press, 2005). See also Daniel Brown, "Islamic Ethics in Comparative Perspective," The Muslim World 89, no. 2 (1999): 181-192, https://onlinelibrary.wiley.com/doi/abs/10.1111/j.1478-1913.1999.tb03677.x.

${ }^{14}$ Nicholas D. Smith, "Some Thoughts about the Origins of 'Greek Ethics,'” The Journal of Ethics 5, no. 1 (March 1, 2001): 4, accessed December 20, 2018, https://doi.org/10.1023/A:1011460723395.

${ }^{15}$ Muhammad Hatta, Alam Pikiran Yunani (Jakarta: UI Press, 1986), 83. 
According to Socrates, the highest goal of human life is to make his soul as pleasant as possible. Human behaviour can only be called reasonable if he tries to obey his heart's desires rather than just obeying the external aspects. ${ }^{16}$ Furthermore, the Socrates word of good is considered good if the way to do it is also right. ${ }^{17}$ According to Socrates, no human has sinned intentionally, and therefore only knowledge is needed by all humans to achieve perfect piety. ${ }^{18}$ This means that for Socrates, this world will be safe and peaceful if humans have knowledge.

Based on the above description, ethics for Socrates is knowledge. Humans will be considered ethical if they have good knowledge about ethics and anything related to it and then practice it in the right way. The purpose is good, with everything related to ethics when one does well so that the possibility of sinning is not there. The smarter or, the more knowledge a person has, the better he is. However, if there are people who are smart and have a lot of knowledge but the ethics are not good, then it means that he is not a smart or knowledgeable person. So, the ethical formula, according to Socrates is smart people $=$ good people.

Furthermore, there is Plato, based on the teachings of his ideas, Plato argues that ideas/souls function to regulate human goals and desires. Between soul, purpose and human lust, all three are related to one another. The relationship between the three can be seen from the pleasure or happiness that humans want. Pleasure is the fundamental goal of human life. The existence of lust will drive people towards things that give pleasure, although lust does not discriminate between good and bad pleasure. So, here, the human soul plays a role in providing the real purpose of pleasure and directing to get good pleasure. From the statement above it can be said that the soul for Plato is the most critical

${ }^{16}$ K. Bertens, Sejarah Filsafat Yunani: Dari Thales ke Aristoteles (Yogyakarta: Kanisius, 1981), 13.

17 T.Z. Lavine, Plato: Kebajikan adalah Pengetahuan (Yogyakarta: Penerbit Jendela, 2003), 16.

${ }^{18}$ Bertrand Russell, Sejarah Filsafat Barat: Kaitannya dengan Kondisi Sosio Politik Zaman Kuno hingga Sekarang, trans. Sigit Jatmiko, $3^{\text {rd }}$ print. (Yogyakarta: Pustaka Pelajar, 2007), 123. 
element for humans to distinguish between good pleasure and wicked pleasure, and the pure soul for Plato is to direct humans to achieve good pleasure. For Plato real pleasure or happiness, that is the goal of human life not felt in the world. Because happiness is located in the soul, not the body, so that if the body and soul are still attached to the dirty body and various interests, and together with various interests of the body, it means that the soul is not happy. ${ }^{19}$ This means that for Plato happiness that really $\mathrm{ca}^{20} \mathrm{n}$ only be felt by humans is in the hereafter.

Plato's disciple, whose ethical thought is worthy of discussion, is Aristotle. As a student of Plato, Aristotle became a philosopher who did not continue his teacher's ideas in specific themes in philosophy. His intelligence on the basic problems of philosophy brought him as a philosopher who was able to provide new ideas in philosophical matters. ${ }^{21}$ This can be seen in his different ethical thinking from his teacher Plato. Regarding Aristotle's ethical thinking, it is not easy to map his thoughts. Because of the vibrant thoughts in his book, because it is limited in two ways, teleological ethics and virtue ethics.

First, Teleological Ethics. Teleology comes from the words telos and logos. Telos means destination. Logos means science. So teleologically speaking is a science of purpose. Teleological ethics, referred to by Aristotle, is moral goodness as the goal of all human actions.22 For Aristotle teleological ethics is divided into two perspectives. First, there is something sought for a further purpose. Second, something is sought for itself. ${ }^{23}$ When looking for a goal, the goal is often to find another destination. For example:

${ }^{19}$ Stumph and Fieser, Socrates to Sartre, 54.

20 Ahmad Tibry, Konsep Bahagia HAMKA: Solusi Alternatif Manusia Modern (Padang: IAIN-IB Press, 2006), 51.

${ }^{21}$ Muhammad Fadil, "Bentuk Pemerintahan dalam Pandangan Aristoteles," KYBERNAN Jurnal Ilmiah Ilmu Pemerintahan 3, no. 1 (2012): 1, accessed December 20, 2018, http://jurnal.unismabekasi.ac.id/index.php/kybernan/article/view/549.

22 Aristoteles, Sebuah "Kitab Suci" Etika Nicomachean Ethics, trans. Embun Kenyowati (Jakarta: Mizan Publika, 2004), vi-vii.

23 Muhammad In'am Esha, "Konsep Pengembangan Diri Aristoteles," Psikoislamika: Jurnal Psikologi dan Psikologi Islam 1, no. 1 (June 30, 2004): 79, accessed December 19，2018， http://ejournal.uin-malang.ac.id/index.php/ psiko/article/view/358. 
when humans get sick, then take medicine to be able to sleep and sleep to be able to restore health. Then, the question arises what people want to find or aim. According to Aristotle, what humans are aiming for is happiness. The ultimate goal and final meaning of human life is happiness. ${ }^{24}$

Second, the ethics of primacy in the middle. Aristotle stated that virtue is a character trait that appears in habitual action. The nature of this "habit" is fundamental because it is necessary that the good thing is carried out continuously. In other words, the character is sturdy and unchanging. ${ }^{25}$ Aristotle was the creator of middle-class ethics, which is a middle between two extremes, each of which is bad. For example, courage is midway between cowardice and recklessness. Thrifty is the middle between extravagance and misery. Self-esteem is midway between pride and humility. Humility is the middle of shyness and shamelessness. ${ }^{26}$

The basic principle of Aristotle's ethics is that humans should live and act in such a way as to achieve a good, quality, successful life. Human life is successful when it reaches the last goal sought through all efforts. ${ }^{27}$ That goal is happiness. Happiness is the ultimate goal of every kindness and action done by humans. ${ }^{28}$ The more people realize their potential as human beings, the more happiness they will enjoy. ${ }^{29}$ This is as Aristotle said in his book "happiness as a sort of good life and good action". ${ }^{30}$ This means that

${ }^{24}$ K. Bertens, Etika (Yogyakarta: Kanisius, 2013), 188-189.

25 Iffan Ahmad Gufron, "Menjadi Manusia Baik dalam Perspektif Etika Keutamaan," Jurnal Yaqzhan: Analisis Filsafat, Agama dan Kemanusiaan 2, no. 1 (June 1, 2016), accessed December 14, 2018, https://syekhnurjati.ac.id/ jurnal/index.php/yaqhzan/article/view/909.

${ }^{26}$ Russell, Sejarah Filsafat Barat, 235.

${ }^{27}$ Frans Magnis Suseno, “Eudemonisme: Epikuros dan Aristoteles," Public Lecture Paper, January 2013, accessed November 7, 2019, http://www. suarakita.org/wp-content/uploads/2013/02/2013-02-02_-_kuliah_umum_filsafat_ etika_yunani_-_jawa_-_franz_magnis-suseno.pdf.

${ }^{28}$ Daniel Bonevac, Today's Moral Issues: Classic and Contemporary Perspectives (Berkeley: Lyn Uhl, 2005), 20.

${ }^{29}$ Suseno, "Eudemonisme."

30 Aristoteles, Nicomachean Ethics, trans. W.D. Ross (Kitchener: Batoche Books, 1999), 12. 
everything is done by humans if it is good and the actions or ways to do it are right then it is called happy. So, everyone's happiness is subjective because everyone has their criteria in determining happiness.

Based on the three opinions regarding ethics from the philosophers of Classical Greece, it can be seen that the three opinions about ethics are displayed in the form of simple concepts. Socrates as the first philosopher to discuss ethics did not explain in detail what ethics and pleasure or happiness was so that his students Plato and Aristotle differed in their opinions in giving meaning to ethics and pleasure or happiness. The existence of differences in concepts between Plato and Aristotle is an abundance of knowledge about ethics, which was subsequently developed by philosophers who came afterwards. Besides, the three figures agreed that the ultimate goal of ethics is to get happiness.

\section{Islamic Ethics}

In the history of Islamic philosophy, various thinkers have tried to formulate ethical concepts, including legal scholars, theologians, mystics and philosophers. This is because ethics or morality in Islam is one of the core teachings of Islam. ${ }^{31}$ Among the crucial problems that are the thoughts of Muslim philosophers in the field of ethics are about happiness. ${ }^{32}$ Their thoughts on ethical issues are more moral guides in behaving in achieving happiness. Ethics in Islam is based on a state of justice, namely to put everything in its portion. Without relativising ethics itself, the value of an act is believed to be relative to the context and purpose of the action itself. ${ }^{33}$

As for the Muslim philosophers who discuss ethics, namely: First, Ibn Miskawayh, for Miskawaih ethics is not only aimed at theoretical knowledge but above all is to enable someone to

31 Nizar, "Pemikiran Etika Ibnu Miskawaih," Aqlam: Journal of Islam and Plurality 1, no. 1 (2016): 36, accessed March 31, 2019, http://journal.iainmanado.ac.id/index.php/AJIP/article/view/498.

${ }^{32}$ Mustain, “Etika dan Ajaran Moral,” 193.

${ }^{33}$ Muhammad Taufik, "Etika dalam Perspektif Filsafat Islam," in Etika: Teori, Praktik, dan Perspektif, ed. Zuhri (Yogyakarta: FA Press, 2016), 49. 
become a better self. It is not enough to know and have such a noble mental state, but more important is to use it and actualize it through actions and actions. Without doing that, no one has the prospect of being a good or virtuous person. ${ }^{34}$ According to Ibn Miskawayh morality is a state of the soul which causes it to act without being thought through or considered in depth. This morality is categorized into two things, namely, given and sought. ${ }^{35}$ This means that for Ibn Miskawayh morality is spontaneity of human actions derived from natural morals in him or morals which have become habits in him.

Ibn Miskawayh also explained about virtue; virtue is the primacy of the middle, which is closely related to the soul that has three powers; thinking power, anger, and willpower. ${ }^{36}$ The power of thinking has the virtue in the midst of al-hikma (wisdom) is the virtue which lies between two fools (al-safh) and stupid (al-balh). The power of angry at having a middle-bold primacy (al-Shaja'ah) is virtue that lies between cowardice ( $a l-j u b n)$ and recklessness ( $a l-$ tahawur). The power of desire to have virtue in the midst of maintaining self-respect (iffah) is a virtue that lies between greed (al- tama') and impotence, lust (al-khumd). ${ }^{37}$ When the three virtues of the middle are harmonious, the primacy of the middle will emerge. Opponents of these three virtues in the midst are ignorant, fearful, greedy, and tyrannical. ${ }^{38}$

Besides discussing ethics, Ibn Miskawayh also discussed happiness. For Ibn Miskawayh, ethics has a relationship with happiness. In according to Ibn Miskawayh, happiness is perfection and the ultimate goal of goodness. ${ }^{39}$ This means that the goal of

${ }^{34}$ Mohd Nasir Omar, “Islamic Social Ethics: An Analysis of Miskawayh's Thought," European Journal of Multidisciplinary Studies 1, no. 1 (April 30, 2016): 82, accessed March 10, 2019, http://journals.euser.org/index.php/ejms/article/ view/1219.

35 Ahmad ibn Muhammad Ibn Miskawayh, Menuju Kesempurnaan Akhlak: Buku Daras Pertama tentang Filsafat Etika, trans. Helmi Hidayat, trans. Helmi Hidayat (Bandung: Mizan, 1994), 56.

36 Ibid., 44.

37 Ibid., 52-53.

${ }^{38}$ Sirajuddin Zar, Filsafat Islam: Filosof dan Filsafatnya (Jakarta: Rajawali Pers, 2012), 136.

${ }^{39}$ Ibn Miskawayh, Menuju Kesempurnaan Akhlak, 91. 
every estuary of every good done by humans is the perfection of happiness. Furthermore, according to Ibn Miskawayh, the goodness and happiness of humans lie in the extent to which humans are able to actualize the potential of the mind in the soul perfectly. ${ }^{40}$

Second, Ibn Bājjah. Ibn Bājjah's ethical thinking was contained in his work entitled Tadbìr al-Mutawahhid. In the book, Ibn Bājjah explained about human actions which are divided into two categories, namely animal actions and human actions. Animal acts are actions based on emotional wills, such as desire, anger, fear, and the like, ${ }^{41}$ that originate from natural desires that are animalistic, but these animal actions can immediately turn into human actions if the goal is the high goals that are by the will of the soul, such as eating and drinking, it is an animal act to fulfil the body's will. However, it can be human if the purpose of eating and drinking is directed at achieving spiritual gifts that are spiritual.

The human action is an action based on the will of the mind, ${ }^{42}$ which at first come from the Absolute and the Eternal, or actions based on consideration of the ratio and the willingness to clean sublime. ${ }^{43}$ The goals behind human actions are high goals. ${ }^{44}$ According to Ibn Bäjjah the point of difference between the two actions is not the action itself but the motive. To explain this difference, he put forward an example like a person who was injured by stumbling with a stone; then he threw the stone. If he throws the stone because it has hurt him, then this is an animal act, so he wants to destroy the stone because it is considered to have bothered him. Another case if he threw the stone so as not to hurt other people, not because of his interests. However, because of his mature thoughts and carefulness of himself later and for others,

${ }^{40}$ Amroeni Drajat, Filsafat Islam: Buat yang Pengen Tahu (Jakarta: Erlangga, 2006), 45.

${ }^{41}$ Ibn Bājjah, Tadbīr al-Mutawaḥhid, (Tunis: Ceres Edition, 1994), 11.

${ }^{42}$ Ibid.

${ }^{43}$ Zar, Filsafat Islam, 197.

44 Yunasril Ali, Perkembangan Pemikiran Falsafi dalam Islam (Jakarta: Bumi Aksara, 1991), 83. 
then this is a human act. ${ }^{45}$ This last act alone can be assessed in the moral field. Because according to Ibn Bājjah, only people who work under the influence of thought and justice solely, and have nothing to do with the animal aspect to it, that alone can be appreciated and can be called the sky, and the right to be discussed by Ibn Bājjah in his book. ${ }^{46}$

Ibnu Bajjah said that the most glorified substance of human action is intellectuality obtained thanks to the perfection of its essence. ${ }^{47}$ This means that the better the human intellect, the better the action because intellectuality is a substance, this means that humans can be measured by their intellectual level. Furthermore, Ibn Bājjah also said that what distinguishes humans from other humans is the intellect or soul that directs humans to be moral. ${ }^{48}$ This means that for Ibn Bäjjah there is an intellectual or mental urge that makes people able to know good and bad and at the same time directs humans to choose moral actions.

According to Ibn Bājjah spiritual actions are actions that make human beings noble, while intellectual actions are actions that make humans holy and virtuous. Humans who have spiritual and intellectual actions are wise people who do good deeds and deeds so that they only focus on the best activities and only share with the best humans in the perfect country. However, said Ibn Bājjah the best is if every individual human race competes with himself to carry out noble and noblest actions. So, this can be said that a person has reached the highest goal, namely when he/she can understand the substance of himself without the help of others. ${ }^{49}$

${ }^{45}$ Ibn Bājjah, Tadbìr al-Mutawahhịid, 10-11.

${ }^{46}$ Ahmad Hanafi, Pengantar Filsafat Islam (Jakarta: Bulan Bintang, 1990), 159.

47 Joaquín Lomba, “El Lugar Del Intelecto Agente En El Pensamiento de Avempace," Revista Española de Filosofía Medieval 9 (October 1, 2002): 41, accessed December 12, 2018, https://www.uco.es/ucopress/ojs/index.php/refime/ article/view/9337.

${ }^{48}$ Joaquín Lomba, “La Ciencia Del Alma En Ibn Bayya (Avempace)," Veritas (Porto Alegre) 52, no. 3 (December 30, 2007): 81, accessed December 20, 2018, http://revistaseletronicas.pucrs.br/ojs/index.php/veritas/article/view/4674.

${ }^{49}$ Josép Puig Montada, "Ibn Bâjja [Avempace]," in The Stanford Encyclopedia of Philosophy, ed. Edward N. Zalta, Spring 2018. (Metaphysics Research Lab, Stanford University, 2018), accessed December 11, 2018, https://plato.stanford.edu/archives/spr2018/entries/ibn-bajja/. 
Third, al-Ghazālī. Al-Ghazālī developed ethical and religious ideas. It is clearly seen that the name of al-Ghazāli in this work in his works finally, after he became a Sufi, no longer uses the expression 'ilm al-akhlāq, but with "the science of the hereafter" ('ilm tarī al-ākhira) or the way which was passed by the prophets and godly ancestors (al-salaf al-sālih). He also named it "practical religion" ('ilm al-mu'ämala). ${ }^{50}$ According to al-Ghazālì ethic is an expression of something that remains in the soul, from which appear actions easily and easily, without the need for thought and research. If from this situation, acts arise good and commendable according to reason and Shari'a as honest, responsible, fair, and so forth, then the situation is called morals. Al-Ghazāli laid down morality not as the ultimate goal of man in his life journey, but as a tool to participate in supporting the principal function of the soul in achieving the highest truth, ma'rifatulläh, in which humans can enjoy his happiness. ${ }^{51}$ Based on the conception of human existence al-Ghazālī divides happiness into two categories, physical happiness and spiritual happiness. The physical happiness is changing and being broken quickly, while spiritual happiness is eternal. ${ }^{52}$ Therefore for al-Ghazālī the highest happiness is happiness in the hereafter, ma' rifatullāh.

Based on the three thoughts of Muslim philosophers regarding ethics, it can be seen that all three argue about ethics that ethics is not only about vertical relations or relations between humans and other humans. But also the horizontal relationship between humans and God. In addition, ethical thinking from Muslim philosophers is also full of high values of religiosity, because ethically can lead people to achieve happiness in life in the world and the hereafter.

${ }^{50}$ Taufik, “Etika dalam Perspektif," 54-55.

${ }^{51}$ Yoke Suryadarma and Ahmad Hifdzil Haq, “Pendidikan Akhlak Menurut Imam Al-Ghazali," At-Ta'dib 10, no. 2 (December 8, 2015): 369-370, accessed March 13， 2018， https://ejournal.unida.gontor.ac.id/index.php/tadib/article/ view/460.

${ }^{52}$ Habibi, "Ilmu dan Eksistensi Kebahagiaan Menurut al-Ghazali," Dirosat: Journal of Islamic Studies 1, no. 1 (June 2016): 80, accessed March 13, 2018, http://ejournal.idia.ac.id/index.php/dirosat/article/view/4. 


\section{Between classical Greek Ethics and Islamic Ethics}

Some Orientalists assume that Islamic philosophy is like a copy-paste from Greek philosophy, while others argue that Islamic philosophy has its own characteristics that are different from Greek philosophy. Orientalists who think that Islamic philosophy is copy-paste or copying seems to be a mistake. Sirajuddin Zar argues that Islamic philosophy is the result of the ideas of Muslims as a whole. The thinking of Muslims is an encouragement of the Qur'an and Hadith teachings. The presence or absence of Greek philosophy / other philosophy, Islamic philosophy will continue to grow and develop. The existence of Greek philosophy or thought of other nations is only as a complement in accelerating the birth process alone. ${ }^{53}$ So, Islamic ethics, as a branch of Islamic Philosophy, is the result of the thoughts of Muslim philosophers themselves despite being influenced by Greek philosophers, as Muslim scholars figures such as al-Fārābī, Ibn Sina and Ibn Miskawayh explain their concept of ethics.

For example al-Fārābī, although his ethical concept was influenced by Plato and Aristotle, but he had a distinctive concept in its own right. His thoughts on ethics and happiness are found in his book Tahṣil al-Sa'ädah and Risālah Tanbīh 'alā Sabīl al-Sa'ädah. In Tahṣil al-Sa'ädah al-Fārābī, the people and citizens of the city to achieve happiness, both in the world and in the hereafter, are when humans fulfil four main characteristics/virtues, namely theoretical virtue, intellectual virtue, moral virtue, and the virtue of amalia. / practical. ${ }^{54}$ Whereas in the book entitled Risālah Tanbīh 'alā Sabīl al-Sa'âdah al-Fārābī explains that morality aims to obtain happiness, ${ }^{55}$ and al-Fārābi also says that happiness is the desired good for good itself. ${ }^{56}$ This means that someone does good is a motive because he likes to do good. The reason someone is doing good is not for anything or because of something. Nevertheless, because it does know goodness is good and extraordinary benefits.

53 Zar, Filsafat Islam, 31.

${ }^{4}$ Abū Naṣr Muḥammad ibn Muḥammad al-Fārābī, Taḥșil al-Sa'ādah (libanon: Dār wa Maktabah al-Hilal, 1995), 25-26.

${ }^{55}$ Abū Naṣr Muḥammad ibn Muḥammad al-Fārābī, Risālah Tanbīh "alā Sabīl al-Sa"ādah (Amman: Yordania University, 1987), 17.

56Ibid., 15. 
From al-Fārābī's thoughts on the ethics above, although influenced by the thoughts of Plato and Aristotle, ${ }^{57}$ it can be seen that alFārābī's ethical thinking has its own concepts and characteristics. The concept of al-Fārābì's happiness is more comprehensive than Plato's and Aristotle's.

From one example of the flow of thought above, it would be wrong if there were still opinions that said that Islamic ethics did not exist. Academically the term ethics originated from Greece, but seeing the substance or nature of ethics itself then in Islam there is the term morality, whose substance is both aimed at making human beings an ethical being on this earth. Although the substance and essence are the same, Greek ethics and Islamic ethics are very different. The differences will be discussed in the next sub-chapter.

\section{Similarities and Differences in Classical Greek Ethics and Islamic Ethics}

Classical Greek ethical thought is a thought that gives an incredible contribution of knowledge in the history of science. The existence of the thoughts of Classical Greek philosophers paved the way for subsequent philosophers in developing ethical concepts. Socrates, who was predicted as the originator of Classical Greek ethics, gave birth to successors, who developed Greek ethics better than before. The important development of Classical Greek ethics is, unfortunately, lacking in one aspect. The absence of spiritual values in it made Classical Greek ethics seem lacking in the eyes of Muslim philosophers. However, it made an opportunity for Muslim philosophers to Islamize the concept in accordance with Islamic style and certainly packed in different packages. This classic Greek atheist style of ethics became the most prominent feature in the development of Classical Greek ethics. Ethics is only limited to the concept of personal moral reinforcement for Athens Greek youth but lacks in providing moral goodness between the person and the Creator and between personal and social relations.

\footnotetext{
${ }^{57}$ See the previous section on the ethical thinking of Plato and Aristotle.
} 
Talking about ethics in Islam, talking about prophetic missions which are the most important after the oneness of Allah SWT (altawhīd). Rasulullah SAW. said: "that I was sent to perfect good morals". 58 This means that Ethics in Islam is not only an aimless theory, but it has a clear purpose, to perfect human morals. The thinking of Muslim philosophers about ethics illustrates the strength of the "Islamic" style in it. Viewed in terms of the usefulness of the ideas put forward by Muslim philosophers to serve as a guide in behaving well and avoiding bad behavior. In addition, the thoughts of Muslim philosophers in the field of ethics cannot be separated from the influence of Sufism teachings. ${ }^{59}$ Ibrahim Madkour even mentions that Sufism is a differentiator between Islamic philosophy and other philosophies. ${ }^{60}$

Seeing Islamic literature on ethics began to take a clearer form in the 8th and 9th centuries AD by researching the principles of the Qur'an and Sunnah by Islamic jurists (fuqaha), theologians (mutakallimin), Sufis, and other scholars, ${ }^{61}$ and with the emergence of books on ethics such as Risāla fi al-Qadr by Hasan al-Bașri, 'Uyun al-Akhbar by Ibn Qutayba, Makārim al-Akhlāq by Ibn Abī al-Dunya, al-Mughni fi Abwāb al-Tawhìd wa al-'Adl by al-Qāọī 'Abd al-Jabbār, Adab al-Dunya wa al-Dīn by al-Mawardi, al-Akhlāq wa al Siyar by Ibn Hazm, and Mīzān al-'Amal by al-Ghazālī. ${ }^{62}$ From the books of Islamic ethics, generally always link goodness and happiness based on the normative Qur'an and Sunnah, which are conveyed with philosophical ideas and with distinctive characteristics of the authors of the book. This means that the discussion of ethics in Islam itself is said to have a tremendous contribution in the history of Islamic and world civilization.

${ }^{58}$ Taufik, “Etika dalam Perspektif," 46-47.

${ }^{59}$ Mustain, “Etika dan Ajaran Moral," 193.

${ }^{60}$ Ibrahim Madkour, Filsafat Islam Metode dan Penerapannya Bagian 1 (Jakarta: Rajawali Pers, 1998), 30.

${ }^{61}$ Mohd Nasir Omar, "Ethics In Islam: A Brief Survey," The Social Sciences 8,

no. 5 (2013): 390, accessed December 20, 2018, https://researchgate.net/ publication/308072115.

${ }^{62}$ Ibid. 
Muhammad Taufik in the book Ethics: Theory, Practice, and Perspective, argues that in the eyes of Islamic philosophy, ethics is loaded with theological content, good value based on the Qur'an and the Sunnah. Starting from the epistemological foundation of religion, ethics in Islam is developed in such a way that can encourage someone to do good deeds, because ethics is a signpost in acting that will guide and remind someone. ${ }^{63}$ The thinking of Muslim philosophers in the field of ethics does not only explain what is good but also at the same time instructs to follow the teachings about the suitable bandage. This means that the study of ethics does not stand alone but is related and integrated with moral teachings. The ultimate goal to be achieved with ethics and moral teachings is happiness which is described as a combination of elements of security, peace and calm. ${ }^{64}$

Also, the distinctive features that distinguish between Classical Greek ethics and Islamic ethics are: first, Classical Greek ethics does not present God in his ethics or is dry from spiritual values (atheism). While Islamic ethics presents God in its ethics or full of spiritual values (theism). This is because in Classical Greek ethics there is no belief in God, so the development of thought that arises is based on the subjectivity of human thought alone and whether or not the size limits that thought. Philosophers provide ethical views in accordance with their experiences, which are sometimes far from the values that bring humans to happiness. In contrast, Islamic ethics is always adorned with spiritual values. The ethics is always based on the belief in the importance of a good and dignified life in this world as a step that brings people closer to humans, nature and God.

Second, the position of classical Greek ethics is only at the level of virtue, while the position of Islamic ethics reaches the level of holiness due to the Qur'an as the source of Islamic ethics. It means that Classical Greek ethics is not a sacred thing in a religion and has nothing to do with God. In contrast to Islamic ethics, where ethics is a sacred thing because the creation of a great ethic is the goal of Islam itself and the purpose of God to send his Messenger

${ }^{63}$ Taufik, “Etika dalam Perspektif," 60-61.

${ }^{64}$ Mustain, “Etika dan Ajaran Moral," 191. 
is to perfect the morals of His servants. So, the creation of great ethics in Islam is God's desire, while Classical Greek ethics is not.

Third, Classical Greek ethics is only limited to discussing human relations with humans, whereas Islamic ethics does not only discuss human relations with humans (hablu min al-nās). But also, the human relationship with the Creator (hablu min Alläh). As is known, the early history in summarizing Classical Greek ethics as science aims to create noble morals for the Athenians at that time so as to create proper connections between people. In contrast to Islamic ethics, the aim is not only to make humans have good morals in social life but also to find out good ways of dealing with Allah, who created such noble morals.

Fourth, Classical Greek ethics cannot adapt to the times, only valid until the time the philosopher existed, and was replaced by the presence of new thoughts. Meanwhile, Islamic ethics can adapt to the times and do not conflict with the Qur'an and Hadith as a source of ethics itself. ${ }^{65}$ In this case, Classical Greek ethics seems to be less than perfect in terms of its survival because it is created based on existing social conditions. While social conditions are developing, so the thoughts created previously no longer answer the existing ethical challenges. In contrast to Islamic ethics, although it also exists based on existing social conditions, Muslin's philosophical thinking about ethics is based on the sources of the Qur'an and Hadith which are always following the development of the times and are always suitable to be practised in each generation.

Fifth, Classical Greek ethics has nothing to do with one's faith. While Islamic ethics is related to faith. The portion of faith in Islamic ethics is a power that enhances and protects ethics, and faith cannot be accepted in the eyes of Islam without relating it to good deeds. ${ }^{66}$ Therefore, ethics in Classical Greece where the

${ }^{65}$ Muhammad Taufik, "Sumber dan Karakteristik Etika Islam", in lectures on Moral / Islamic Ethics in the Aqidah and Philosophy of Semester 1 (S2) majors, on Tuesday, October 16, 2018, hours. 3:00 p.m.

66 Al-Hasan al-Haidaros, Faridahwati Mohd. Shamsudin, and Kamil Md. Idris, "Ethics and Ethical Theories from an Islamic Perspective," International Journal of Islamic Thought 4 (December 2013), accessed December 20, 2018, 
ultimate goal of happiness is only the dimension of "kedisiniaan" while ethics in Islam with happiness as the ultimate goal also includes the dimensions of "kedisanaan" or eschatological. ${ }^{67}$ This means that Classical Greek ethical thought that is applied in everyday life of society is only as a form of development as a human being. High and low levels of ethics have absolutely nothing to do with one's faith or beliefs. This is the implication of the absence of beliefs about God, regarding the last day, heaven and hell so that human actions are believed to be the limit when humans have died. It is different from Islamic ethics which links ethics and faith because it believes that life in this world is not the end of everything. There is life after death, and belief in God and heaven and hell becomes a logical reason for human actions. The better the human ethics, the better the faith and this determines the steps to achieve world happiness with the dimension of "kedisiniaan (here-ness)" and "kedisanaan (there-ness)".

From the description above, it can be concluded that the most fundamental difference between classical Greek ethics and Islamic ethics lay on the fundamental values. While ethics in Islam are influenced and shaped by the spiritually and religious norms, classical Greek ethics tend to move away from such values.

\section{Conclusion}

Classical Greek ethics and Islamic ethics are different. Although being influenced by classical Greek ethics, Islamic ethics is not totally derived from its predecessor. Islamic ethics has its own style and distinctiveness. Classical Greek ethics does not present spiritual values in its ethical teachings (atheism), while Islamic ethics presents divine values (theism). Classical Greek ethics is only at the level of primacy, while Islamic ethics reaches the peak of sanctity because it refers to the divine sources, namely the Qur'an. Furthermore, classical Greek ethics only deals with human relations with humans, while Islamic ethics addresses not only human relations, but also human relations with God.

http://www.ukm.my/ijit/wp-content/uploads/2016/01/IJIT-Vol-4-Dec-2013_1_113.pdf.

${ }^{67}$ Esha, “Konsep Pengembangan Diri," 82. 
The other differences lay on the fact that classical Greek ethics is not in line with the times or does not adapt to the times, while Islamic ethics can adapt to the development of the times as well as in line with its scriptural sources. Moreover, classical Greek ethics is not related to one's faith, while Islamic ethics is related to one's faith.

\section{Reference}

Ali, Yunasril. Perkembangan Pemikiran Falsafi dalam Islam. Jakarta: Bumi Aksara, 1991.

Amin, Ahmad. Etika (Ilmu Akhlak). Jakarta: Bulan Bintang, 1983.

Aristoteles. Nicomachean Ethics. Translated by W.D. Ross.

Kitchener: Batoche Books, 1999.

- - - Sebuah "Kitab Suci" Etika Nicomachean Ethics. Translated by Embun Kenyowati. Jakarta: Mizan Publika, 2004.

Baqir, Haidar. Islam Risalah Cinta dan Kebahagiaan. Jakarta: Mizan, 2012.

Bertens, K. Etika. Yogyakarta: Kanisius, 2013.

---. Sejarah Filsafat Yunani: Dari Thales ke Aristoteles. Yogyakarta: Kanisius, 1981.

Bonevac, Daniel. Today's Moral Issues: Classic and Contemporary Perspectives. Berkeley: Lyn Uhl, 2005.

Brown, Daniel. "Islamic Ethics in Comparative Perspective." The Muslim World 89, no. 2 (1999): 181-192. https://onlinelibrary. wiley.com/doi/abs/10.1111/j.1478-1913.1999.tb03677.x.

Drajat, Amroeni. Filsafat Islam: Buat yang Pengen Tahu. Jakarta: Erlangga, 2006.

Esha, Muhammad In'am. "Konsep Pengembangan Diri Aristoteles." Psikoislamika: Jurnal Psikologi dan Psikologi Islam 1, no. 1 (June 30, 2004): 76-83. Accessed December 19, 2018. http://ejournal.uin-malang.ac.id/index.php/psiko/article/view/ 358.

Fadil, Muhammad. "Bentuk Pemerintahan dalam Pandangan Aristoteles." KYBERNAN Jurnal Ilmiah Ilmu Pemerintahan 3, no. 1 (2012): 1-9. Accessed December 20, 2018. http://jurnal. unismabekasi.ac.id/index.php/kybernan/article/view/549. 
al-Fārābī, Abū Nașr Muhammad ibn Muhammad. Risālah Tanbīh "alā Sabīl al-Sa"ädah. Amman: Yordania University, 1987.

- - - Tahșil al-Sa'ādah. libanon: Dār wa Maktabah al-Hilal, 1995.

Gufron, Iffan Ahmad. "Menjadi Manusia Baik dalam Perspektif Etika Keutamaan." Jurnal Yaqzhan: Analisis Filsafat, Agama dan Kemanusiaan 2, no. 1 (June 1, 2016). Accessed December 14, 2018. https://syekhnurjati.ac.id/jurnal/index.php/yaqhzan/ article/view/909.

Habibi. "Ilmu dan Eksistensi Kebahagiaan Menurut al-Ghazālī." Dirosat: Journal of Islamic Studies 1, no. 1 (June 2016): 75-86. Accessed March 13， 2018. http://ejournal.idia.ac.id/ index.php/dirosat/article/view/4.

al-Haidaros, Al-Hasan, Faridahwati Mohd. Shamsudin, and Kamil Md. Idris. "Ethics and Ethical Theories from an Islamic Perspective." International Journal of Islamic Thought 4 (December 2013). Accessed December 20, 2018. http://www.ukm.my/ijit/wp-content/uploads/2016/01/IJIT-Vol4-Dec-2013_1_1-13.pdf.

Hanafi, Ahmad. Pengantar Filsafat Islam. Jakarta: Bulan Bintang, 1990.

Hatta, Muhammad. Alam Pikiran Yunani. Jakarta: UI Press, 1986.

Ibn Bājjah. Tadbīr al-Mutawahhid. Tunis: Ceres Edition, 1994.

Ibn Miskawayh, Ahmad ibn Muhammad. Menuju Kesempurnaan Akhlak: Buku Daras Pertama tentang Filsafat Etika, trans. Helmi Hidayat. Translated by Helmi Hidayat. Bandung: Mizan, 1994.

Lavine, T.Z. Plato: Kebajikan adalah Pengetahuan. Yogyakarta: Penerbit Jendela, 2003.

Lomba, Joaquín. "El Lugar Del Intelecto Agente En El Pensamiento de Avempace." Revista Española de Filosofía Medieval 9 (October 1, 2002): 33-48. Accessed December 12, 2018. https://www.uco.es/ucopress/ojs/index.php/refime/ article/view/9337.

- - - "La Ciencia Del Alma En Ibn Bayya (Avempace)." Veritas (Porto Alegre) 52, no. 3 (December 30, 2007): 79-90. Accessed December 20, 2018. http://revistaseletronicas.pucrs.br/ojs/ index.php/veritas/article/view/4674.

Madkour, Ibrahim. Filsafat Islam Metode dan Penerapannya Bagian 1. Jakarta: Rajawali Pers, 1998. 
Mahmood, Saba. The Politics of Piety: The Islamic Revival and the Feminist Subject. Princeton: Princeton University Press, 2005.

Maksum, Ali. Pengantar Filsafat: Dari Masa Klasik hingga Postmodernisme. Yogyakarta: Ar-Ruzz Media, 2011.

Mangunhardjana, A. Isme-Isme dalam Etika dari A sampai Z. Yogyakarta: Penerbit Kanisius, 1997.

Montada, Josép Puig. "Ibn Bâjja [Avempace]." In The Stanford Encyclopedia of Philosophy, edited by Edward N. Zalta. Spring 2018. Metaphysics Research Lab, Stanford University, 2018. Accessed December 11, 2018. https://plato.stanford.edu/ archives/spr2018/entries/ibn-bajja/.

Mustain. "Etika dan Ajaran Moral Filsafat Islam: Pemikiran Para Filosof Muslim tentang Kebahagiaan." Ulumuna 17, no. 1 (2013): 191-212. Accessed November 11, 2018. https://ulumuna.or.id/index.php/ujis/article/view/239.

Nizar. "Pemikiran Etika Ibnu Miskawaih." Aqlam: Journal of Islam and Plurality 1, no. 1 (2016): 35-42. Accessed March 31, 2019. http://journal.iainmanado.ac.id/index.php/AJIP/article/view/498.

Omar, Mohd Nasir. "Ethics In Islam: A Brief Survey." The Social Sciences 8, no. 5 (2013): 387-392. Accessed December 20, 2018. https://researchgate.net/publication/308072115.

- - - "Islamic Social Ethics: An Analysis of Miskawayh's Thought." European Journal of Multidisciplinary Studies 1, no. 1 (April 30, 2016): 81-87. Accessed March 10, 2019. http://journals.euser.org/index.php/ejms/article/view/1219.

Russell, Bertrand. Sejarah Filsafat Barat: Kaitannya dengan Kondisi Sosio Politik Zaman Kuno hingga Sekarang. Translated by Sigit Jatmiko. 3rd print. Yogyakarta: Pustaka Pelajar, 2007.

Singer, Peter. Ethics. England: Oxford Readers, 1994.

Smith, Nicholas D. "Some Thoughts about the Origins of 'Greek Ethics.'" The Journal of Ethics 5, no. 1 (March 1, 2001): 3-20. Accessed December 20, 2018. https://doi.org/10.1023/ A:1011460723395.

Stumph, Samuel Enoch, and James Fieser. Socrates to Sartre and Beyond: A History of Philosophy. 8th ed. New York: McGrawHill, 2008. 
Suryadarma, Yoke, and Ahmad Hifdzil Haq. "Pendidikan Akhlak Menurut Imam Al-Ghazālī." At-Ta'dib 10, no. 2 (December 8, 2015): 361-381. Accessed March 13, 2018. https://ejournal. unida.gontor.ac.id/index.php/tadib/article/view/460.

Suseno, Frans Magnis. Public Lecture Paper. "Eudemonisme: Epikuros dan Aristoteles." Public Lecture Paper, January 2013. Accessed November 7, 2019. http://www.suarakita.org/wpcontent/uploads/2013/02/2013-02-02_-_kuliah_umum_filsafat_ etika_yunani_-_jawa_-_franz_magnis-suseno.pdf.

Taufik, Muhammad. "Etika dalam Perspektif Filsafat Islam." In Etika: Teori, Praktik, dan Perspektif, edited by Zuhri, 35-64. Yogyakarta: FA Press, 2016.

Tibry, Ahmad. Konsep Bahagia HAMKA: Solusi Alternatif Manusia Modern. Padang: IAIN-IB Press, 2006.

Walidah, Iffah Al. "Tabayyun Di Era Generasi Millenial." Jurnal Living Hadis 2, no. 2 (October 7, 2017): 317-344. Accessed March 13, 2019. http://ejournal.uin-suka.ac.id/ushuluddin/ Living/article/view/1359.

Zar, Sirajuddin. Filsafat Islam: Filosof dan Filsafatnya. Jakarta: Rajawali Pers, 2012. 